\title{
Reproductive Characteristics of Pitayo (Stenocereus queretaroensis) and their Relationships with Soluble Sugars and Irrigation
}

\author{
Eulogio Pimienta-Barrios \\ Division de Ciencias Biológicas, Centro de Ciencias Biológicas y Agropecuarias, Universidad de \\ Guadalajara, Nextipac, Zapopan, Jalisco, México \\ Park S. Nobel ${ }^{1}$ \\ Department of Biology and UCLA-DOE Laboratory, University of California, Los Angeles, \\ CA 90024-1606
}

Additional index words. Stenocereus, fruit quality, phenology, reproductive demography, seed germination, seed quality, vegetative growth

\begin{abstract}
Flower and fruit production by the columnar cactus, Stenocereus queretaroensis (W eber) B uxbaum, occurred during the dry season in the late winter and spring, and the relatively small annual stem extension occurred primarily during the fall. Thus, reproductive growth does not directly compete with vegetative growth for resources such as reducing sugars, which increased during the wet summer season, a period when total sugars were decreasing. Stem extension, reproductive demography, fruit quality, seed size, and seed quality were not influenced by irrigation. Final fruit size and seed germination, however, were enhanced by applying water. The times from flower bud differentiation to flower opening and from anthesis to fruit ripening were relatively short and unaffected by irrigation.
\end{abstract}

Pitayos (Stenocereus spp.) are columnar cacti native to subtropical regions of Mexico that produce attractively colored edible fruit (Bravo, 1978). Pitayo cultivation using relatively low inputs of anthropogenic energy has increased the economic viability of small and medium farms in Mexico, because the fruit ripen before local markets are supplied with other summer fruit (PimientaBarrios and Nobel, 1994). Although pitayos have been cultivated in Mexico for over 100 years, efforts to improve this fruit crop are rather recent and have been made primarily by selecting outstanding phenotypes, with emphasis on fruit quality rather than biomass productivity (Nobel and Pimienta-Barrios, 1995). As is the case for many undomesticated fruit, the reproductive development of Stenocereus is asynchronous (Lomeli and Pimienta, 1993) and the rate of net $\mathrm{CO}_{2}$ uptake is relatively low (Nobel and PimientaBarrios, 1995). Reproductive and vegetative growth occur during the dry season, presumably drawing on resources from the previous wet summer season (Robles, 1994).

To help understand the relation between growth and carbohydrate resources, reproductive and vegetative growth of $S$. queretaroensis were periodically determined and related to the monthly variations in the content of total and reducing sugars. Also, the water supply was manipulated by irrigating certain plants to compare genetic vs. environmental influences on growth. In particular, whether stem extension, reproductive effort, and accumulation of soluble sugars were water limited was examined.

Received for publication 10 Apr. 1995. Accepted for publication 10 Aug. 1995. Research was conducted at Techaluta, Jalisco, Mexico. Use of trades names does not imply endorsement of the products named nor criticism of similar ones not named. Field observations were competently made by Celia Robles and Alejandro Dominguez and laboratory measurements by Lucila Mendez. Data in Table 2 were kindly obtained by Ning Wang. This research was financially supported by the UCLA Committee on Research and CONACYT grant 2083-N9302. The cost of publishing this paper was defrayed in part by the payment of page charges. Under postal regulations, this paper therefore must be hereby marked advertisement solely to indicate this fact.

'To whom reprint requests should be addressed.

\section{Materials and Methods}

Study site andplants. The study was conducted during 1993 and the first half of 1994 at acommercial pitayo plantation in Techaluta, Jalisco, Mexico, that can produce 15 tons fresh weight of fruit/ha per year (Pimienta-Barrios and Nobel, 1994). The site is in the Sayula Basin in the southern part of Jalisco at $20^{\circ} 05^{\prime}$ north latitude, $103^{\circ} 32^{\prime}$ west longitude, and $1380 \mathrm{~m}$ above sea level. Daily air temperatures and rainfall were obtained from an official weather station maintained by the Comisión National del Agua, Delegación Jalisco, at Atoyac $\left(20^{\circ} 1^{\prime} \mathrm{N}, 103^{\circ} 32^{\prime} \mathrm{W}, 1373 \mathrm{~m}\right)$.

Mature plants of $S$. queretaroensis var. Mamey (the most important locally cultivated variety) were used. Such arborescent cacti are up to $6 \mathrm{~m}$ tall, have a well-defined trunk and many relatively vertical branches, and bear flowers from areoles on the generally eight prominent ribs of their cylindrical stems (Pimienta and Nobel, 1994). Four stems, one located in each of the four cardinal directions, were monitored on six, initially 17-year-old, plants. The length of each branch was measured using a calibrated ruler whose lower part was aligned with a reference mark on the stem.

Soluble sugars. Tissue samples for total and reducing sugars were excised with a razor blade at midheight from the experimental plants at monthly intervals from June 1993 to July 1994. The samples were removed from the crest of ribs pointing in each of the four cardinal directions on each of the six plants. Each sample extended $15 \mathrm{~mm}$ along each side of a rib, weighed about $1 \mathrm{~g}$, and contained approximately equal amounts of chlorenchyma and water-storage parenchyma. After the four samples were homogenized in a blender, soluble sugars were extracted with $10 \mathrm{ml}$ of $80 \%$ ethanol at $75 \mathrm{C}$ for $5 \mathrm{~min}$; the weights of reducing sugars and total sugars were expressed in glucose equivalents (Carnal and Black, 1989).

Irrigation. From December 1993 to July 1994, the effects of water supply on growth and sugar content were monitored for an additional seven plants of the same age. The equivalent of $45 \mathrm{~mm}$ of precipitation was applied each week (a total of $1260 \mathrm{~mm}$ during 
a period with only $66 \mathrm{~mm}$ rainfall) over a $2.5-\mathrm{m}^{2}$ area around each of these plants. To study the effects of irrigation on reproductive development, the number of flowers initiated, the number of flowers that reached anthesis (flower opening), and the number of fruit that reached maturity were recorded weekly. After the flower buds emerged from the areole, axial growth of 50 flowers from plants under natural conditions and 50 from those irrigated were also measured weekly until anthesis; measurements on successfully fertilized flowers were continued until the fruit reached maturity.

Fruit and seed characteristics. To study the effects of water supply on fruit and seed quality, 20 fruit were collected under each condition, weighed, and peeled. After squeezing the pulp through cheesecloth, the seeds were counted and weighed. The $\mathrm{pH}$ of the pulp was measured and the total soluble solids were determined using a Reitcher-Jung 10432 refractometer with temperature compensation. Also, pulp ( $2 \mathrm{~g}$ ) was homogenized with $5 \mathrm{ml}$ of $80 \%$ acetone at $4 \mathrm{C}$ and centrifuged at $10,000 \times \mathrm{g}$ for $20 \mathrm{~min}$, and the supernatant fluid was used for determining total soluble sugars. Pulp protein was determined according to Choe and Thimamr (1975), using the method of Lowry et al. (1951).

Seeds $(0.2 \mathrm{~g})$ were oven-dried at $70 \mathrm{C}$ until they reached constant weight ( 3 days), ground to a fine powder with sand, and then extracted three times with $5 \mathrm{ml}$ of (v/v> 2 chloroform : 1 methanol. After centrifugation, the supernatant fluid was dried at $50 \mathrm{C}$ to yield the lipid fraction (Harborne, 1984). To determine starch, the pellet was extracted three times with $10 \mathrm{ml}$ of (by volume) 12 methanol : 5 chloroform : 3 water and then twice with $10 \mathrm{ml}$ of distilled water. After centrifugation, the insoluble fraction was boiled for $2 \mathrm{~h}$ in 2 $\mathrm{ml}$ of distilled water; $4 \mathrm{ml}$ of $50 \mathrm{~mm}$ sodium acetate $(\mathrm{pH} 4.5)$ containing 50 units of amyloglucosidase were added to hydrolyze the starch before glucose determination (Haissig and Dickson,

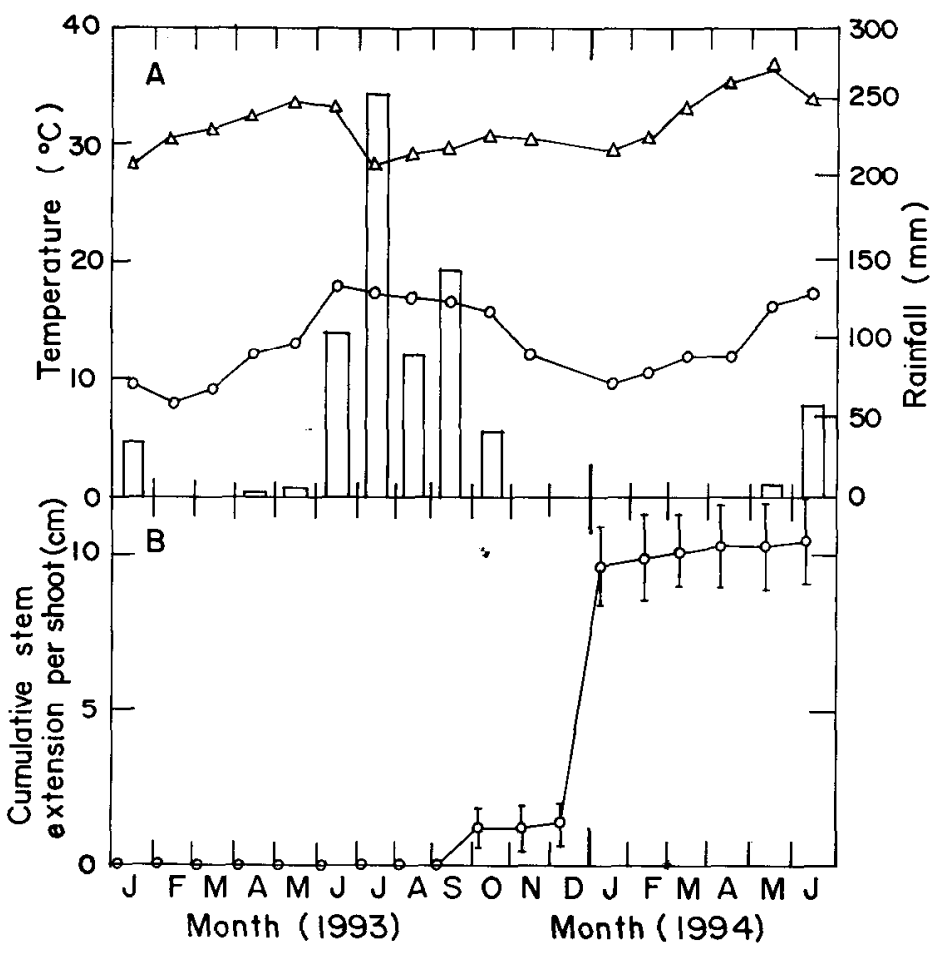

Fig. 1. Daily minimum $(\bigcirc)$ and maximum $(\Delta)$ air temperatures averaged over a month and total monthly rainfall (bars) (A) and monthly stem extension for Stenocereus queretaroensis (B) in the Sayula Basin, Jalisco, Mexico. Extension data are means $\pm \mathrm{SE}$, except when the error bars are smaller than the symbol $(\mathrm{n}=$ 24 stems).
1979). After starch hydrolysis, nonstarch polysaccharides were collected by centrifugation, washed three times with $10 \mathrm{ml}$ of distilled water, and then extracted with $2 \mathrm{ml}$ of $30 \%$ (v/v) perchlotic acid for $1 \mathrm{~h}$ (Sutton, 1975). Total hexose was determined by a sulfuric acid-phenol reagent (Sturgeon, 1990). Seed protein was determined as for the pulp protein.

Seedgermination. To test germination, 10 replicates of 20 seeds each for both watering conditions were placed on two layers of Whatman no. 1 filter paper at 20C in a 9-cm-diameter petri dish and provided with $8 \mathrm{ml}$ of distilled water. Germination, scored when the radicle was $>1 \mathrm{~mm}$, was recorded every 2 days. Seeds were either in the light (a photosynthetic photon flux of $100 \mu \mathrm{mol} \cdot \mathrm{m}^{-2} \cdot \mathrm{s}^{-1}$ provided for $12 \mathrm{~h}$ daily by incandescent lamps) or in the dark.

Analysis of variance was performed on the final percentage of seed germination, regarding plants or petri dishes as units in a randomized block design.

\section{Results}

Climate and stem extension. Mean daily extreme air temperatures in the Sayula Basin averaged over a month in 1993 ranged from a low of 8 to $18 \mathrm{C}$ at night and from a high of 28 to $34 \mathrm{C}$ during the day (Fig. 1A). During the first half of 1994, the mean daily extreme air temperatures were slightly higher than in 1993, but again the warmest month was May, which was just before the rainy season. The rainfall for 1993 totaled $660 \mathrm{~mm}, 75 \%$ occurring in June through August; during the first half of 1994, $67 \mathrm{~mm}$ occurred in May and June. The dry season began in late November 1993 and extended until early May 1994 (Fig. 1A).

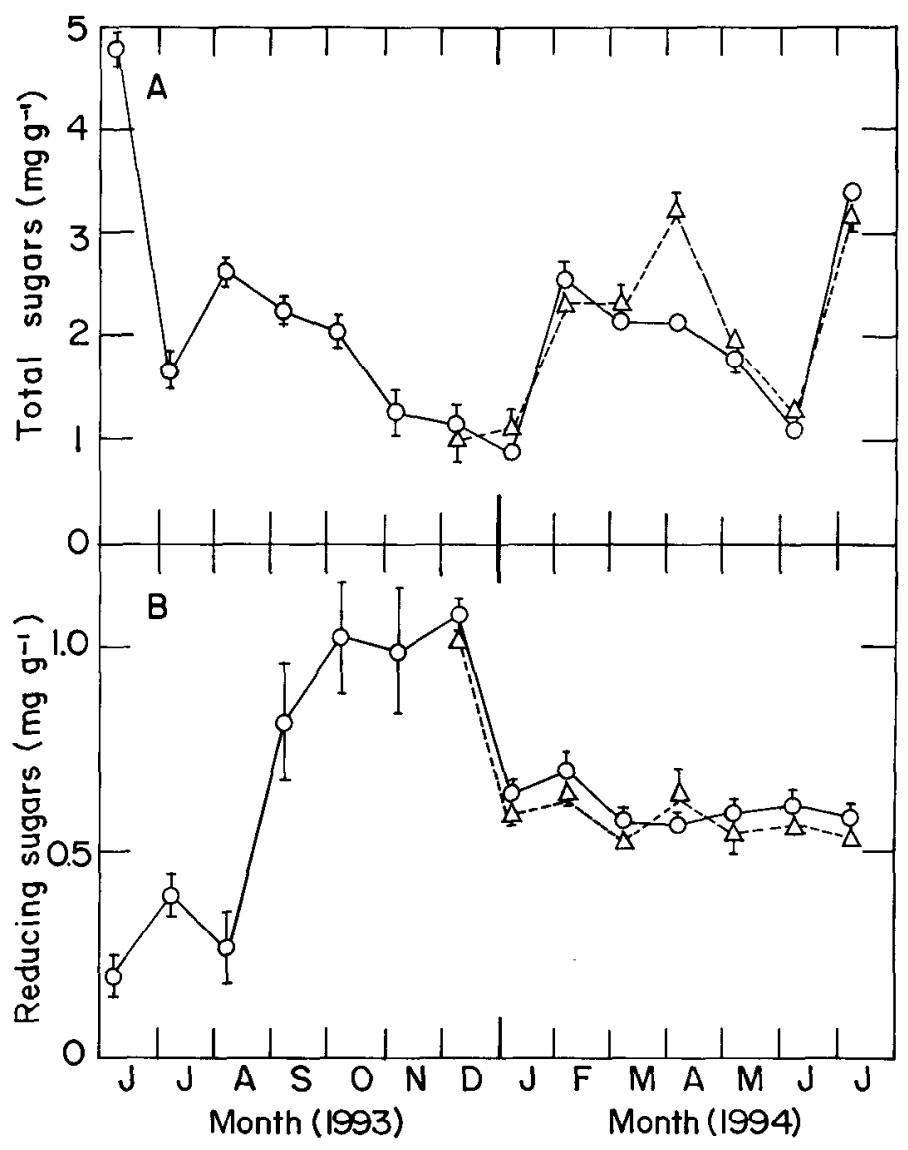

Fig. 2. Monthly levels of total soluble sugars (A) and reducing sugars (B) for Stenocereus queretaroensis. Irrigation (dashed line) began on 21 Dec. 1993. Data are on a fresh weight basis ( $\mathrm{n}=6$ or 7 plants). 
Major monthly stem extension of $S$. queretaroensis started in September 1993 and continued through the end of the year (Fig. 1B). Actually, $85 \%$ of the annual growth occurred from 4 Dec. 1993 to 5 Jan. 1994 , when the daily rate was $0.26 \mathrm{~cm} \cdot$ day $^{-1}$. Stem extension was minimal from January to August (Fig. 1B), leading to an annual rate of only $0.027 \mathrm{~cm} \cdot \mathrm{day}^{-1}$. When the plants were irrigated beginning on 21 Dec. 1993, also no appreciable stem extension occurred from 5 Jan. through July 1994 (data not shown).

Stem sugars. Total soluble sugars per unit of stem fresh weight declined from June through November 1993 and increased sharply in December 1993 and again in June 1994 (Fig. 2A). Reducing

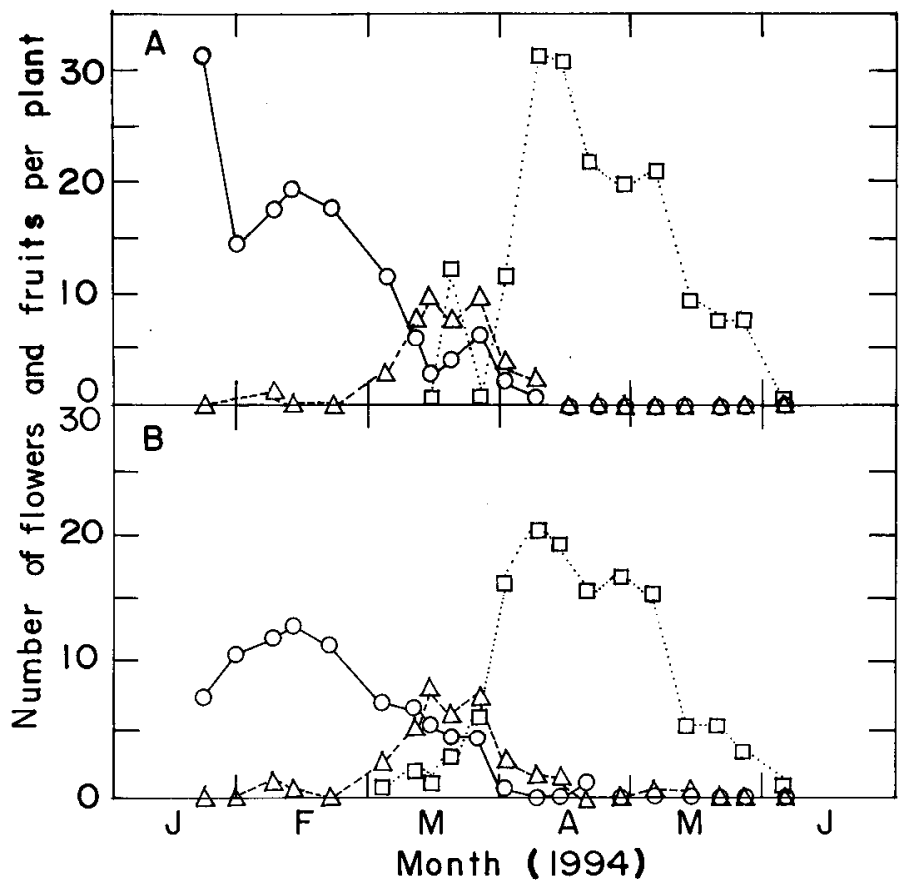

Fig. 3. Reproductive development for Stenocereus queretaroensis under natural conditions (A) and with irrigation (B). Number of emerging flower buds ( $\bigcirc$ ), open flowers $(\Delta)$, and nearly ripe fruits $(\square$; the decline in number toward the end of the season was the result of periodic fruit harvesting) are means $\pm \operatorname{SE}(n=6$ or 7 plants).

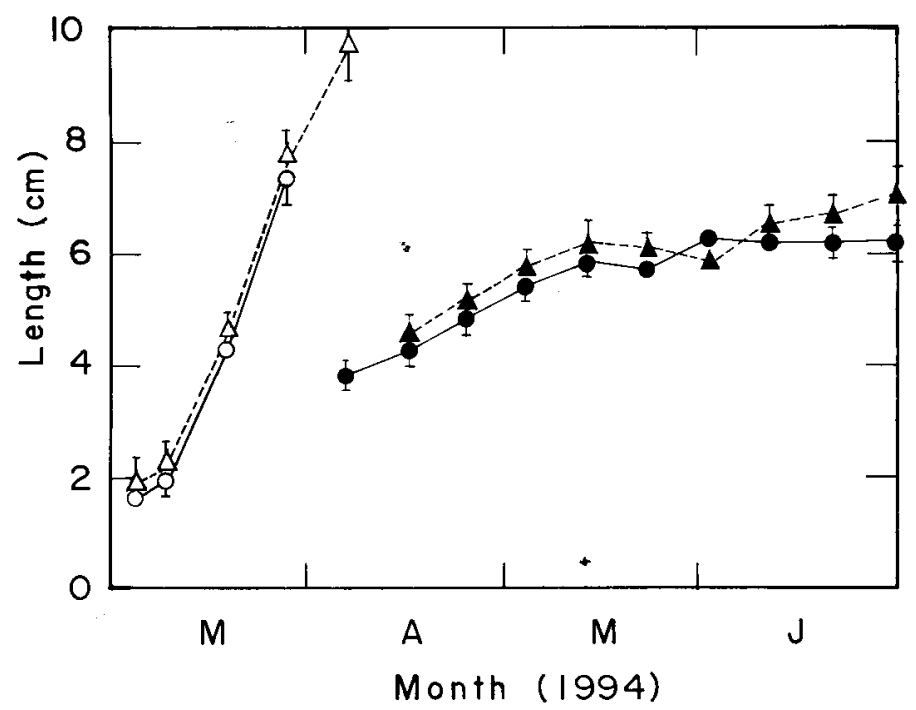

Fig. 4. Length of flower buds (receptacle plus perianth; $\odot^{-}, \Delta$ ) and the subsequently developing fruits ( $\mathbf{\Delta}$ ) for Stenocereus queretaroensis under natural conditions ( $\bigcirc$ ) and with irrigation $(\Delta, \boldsymbol{\Delta})$. Data are means $\pm \operatorname{SE}(\mathrm{n}=50$ flowers or fruit). sugars had opposite temporal patterns than total sugars from June through September 1993, as they then increased (Fig. 2B). From February to June 1994, total sugars decreased and reducing sugars were relatively constant. Reducing sugars represented only about $3 \%$ of the total sugars in June 1993 but $92 \%$ in December 1993. When the plants were irrigated beginning in December, total sugars gradually increased from January to April 1994 but then had a pattern similar to plants under natural conditions (Fig. 2A). Monthly levels of reducing sugars were similar for irrigated and unirrigated plants from January to April 1994 (Fig. 2B).

Reproductive development. Flower buds were initiated over 2 months beginning at the end of January 1994, with greater early initiation under natural conditions (Fig. 3A) than for irrigated plants (Fig. 3B). The total number initiated under natural conditions averaged 266 per plant, decreasing to 170 per plant $(\mathrm{P}<0.05)$ under irrigation. Although individual flowers were open for only 1 to 2 days, the period with a substantial number of open flowers per plant was about 1 month (Fig. 3). The number of flowers that underwent anthesis averaged 98 per plant under natural conditions but only 31 per plant $(\mathrm{P}<0.01)$ when irrigated. A substantial number of ripening fruit occurred over 2 months (Fig. 3). The number of harvested fruit averaged 73 per plant under natural conditions and 70 per plant under irrigation $(\mathrm{P}<0.01)$.

The rate of flower bud growth was similar under natural and irrigated conditions, but about 22 days elapsed from the emergence of the flower buds to anthesis under natural conditions and 31 days with irrigation (Fig. 4). Thus, flowers (receptacle plus perianth) became $30 \%$ longer under irrigation. After abscission of the perianth, the developing fruit were about $15 \%$ longer for irrigated plants compared with those under natural conditions. Fruit length reached $90 \%$ of its final size in about 40 days, and the overall development period from anthesis to maturity was about 60 days (Fig. 4).

Flower, fruit, and seed characteristics. Under natural conditions, $976 \pm 53$ (mean $\pm \mathrm{SE}, \mathrm{n}=10$ ) ovules occurred per flower and $796 \pm 68$ seeds occurred per fruit, or a seed set of $79 \%$; for irrigated plants, the numbers were higher, $1102 \pm 29(\mathrm{P}<0.05)$ and $1020 \pm$ 60 ( $\mathrm{P}<0.01)$, respectively, or a seed set of $92 \%$. Watering increased individual fruit weight by $18 \%(\mathrm{P}<0.05$; Table 1$)$. However, the $\mathrm{pH}$ and the contents of total soluble solutes, sugars, and protein were unaffected by irrigation. Total seed weight per fruit was $32 \%$ higher for irrigated plants $(\mathrm{P}<0.01)$.

The main reserve in $S$. queretaroensis seeds was lipid, which comprised $25 \%$ to $27 \%$ of the total dry weight compared to $<1 \%$ for polysaccharides (Table 2). Protein comprised $14 \%$ to $17 \%$ of the total dry weight. Contents of lipids and nonstarch polysaccharide were higher and protein was lower under natural conditions compared with irrigated plants $(\mathrm{P}<0.05$; Table 2$)$.

Table 1. Fruit characteristics of Stenocereus queretaroensis growing under two water conditions. Data are means $\pm \operatorname{SE}(n=20$ fruit).

\begin{tabular}{lcc}
\hline \hline Quantity & \multicolumn{2}{c}{ Condition } \\
\cline { 2 - 3 } (fresh wt basis) & Natural & Irrigated \\
\hline Fruit weight $(\mathrm{g})$ & $102.0 \pm 4.3$ & $120.0 \pm 4.6$ \\
$\mathrm{pH}$ & $4.5 \pm 0.3$ & $4.1 \pm 0.2$ \\
Total soluble solutes $(\%)$ & $10.7 \pm 0.8$ & $10.6 \pm 0.9$ \\
Sugars $\left(\mathrm{mg} \cdot \mathrm{g}^{-1}\right.$ ) & & \\
$\quad$ Total & $5.6 \pm 0.8$ & $5.8 \pm 0.4$ \\
$\quad$ Reducing & $3.4 \pm 0.4$ & $3.6 \pm 0.6$ \\
Protein (mg. $\left.{ }^{-1}\right)$ & $1.51 \pm 0.09$ & $1.73 \pm 0.07$ \\
Seed weight $(\mathrm{g})$ & $1.98 \pm 0.06$ & $2.62 \pm 0.08$ \\
\hline
\end{tabular}


Table 2. Seed characteristics of Stenocereus queretaroensis growing under two water conditions. Data are means $\pm S E$ ( $n=4$ plants).

\begin{tabular}{lcc}
\hline \hline Quantity & \multicolumn{2}{c}{ Condition } \\
\cline { 2 - 3 }$(\%$ by dry wt $)$ & N a t u r a 1 & Irrigated \\
\hline Lipid & $27.0 \pm 0.2$ & $25.2 \pm 0.3$ \\
Starch & $0.19 \pm 0.01$ & $0.20 \pm 0.01$ \\
Nonstarch polysaccharide & $0.42 \pm 0.02$ & $0.25 \pm 0.02$ \\
Protein & $14.1 \pm 0.7$ & $16.5 \pm 0.7$
\end{tabular}

Seed germination. Seeds from fruit of irrigated plants germinated more rapidly in the light than seeds from fruit of plants under natural conditions (Fig. 5). Irrigation increased the percentage of seeds that germinated within 3 days from $1 \%$ to $21 \%$. Final seed germination was $35 \%$ higher for irrigated plants $(P<0.01$; Fig. 5). No seeds germinated for either water condition (200 seeds each) when maintained in continuous darkness for 16 days.

\section{Discussion}

Vegetative growth for S. queretaroensis does not coincide with reproductive growth, as it does for most conventional fruit crops in temperate and tropical regions (Ryugo, 1988). The time offset of vegetative and reproductive activities reduces competitive sink effects, regulating assimilate partitioning to different organs, which may help S. queretaroensis adapt to water-limited environments. Soluble sugars accumulate both in early summer just after reproductive growth and in early winter after the sharp pulse of stem extension; reducing sugars such as glucose and fructose increase during the summer as total sugars decrease. This columnar cactus thus behaves like a deciduous plant, for which seasonal cycles in carbohydrate accumulation are more pronounced than in evergreen plants (Kozlowski et al., 1991). It also behaves similarly to tree species in dry tropical regions, whose flowering and fruiting coincide with the dry season and whose vegetative growth is not initiated until flowering ceases (Jansen, 1967; Longino, 1986). The absence of reproductive growth and the relatively low stem extension by $S$. queretaroensis during the wet summer season suggest that it then stores starch in its stems and perhaps also extends its root system.

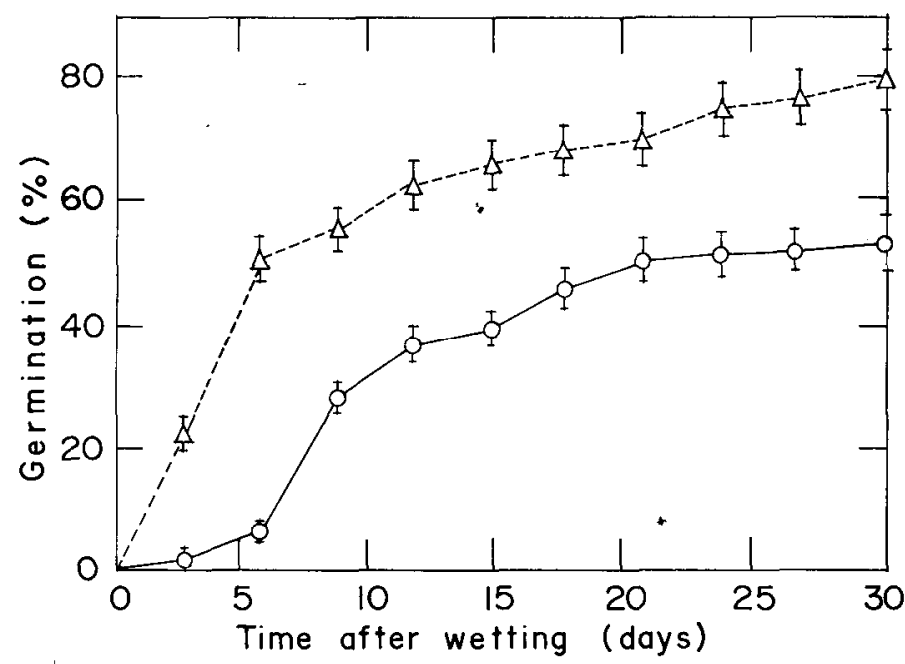

Fig. 5. Time course for germination of Stenocereus queretaroensis seeds under natural conditions $(O)$ or with irrigation $(\Delta)$. Data are for seeds germinating on wet filter paper in the light and are means \pm SE $(n=10$ replicates of 20 seeds each).
The growth rate of $S$. queretaroensis is similar to that of other columnar cacti producing edible fruit (Nerd et al., 1993). The mean annual stem extension for $S$. thurberi in its native habitat averages $9 \mathrm{~cm} \cdot y^{-1} \mathrm{r}^{-1}$ for young plants $(<1 \mathrm{~m} \mathrm{tall})$ and $5 \mathrm{~cm} \cdot \mathrm{year}^{-1}$ for mature plants (>2 m tall; Parker, 1988); the annual stem extension for S. queretaroensis in a region with about three times as much annual rainfall is about $22 \mathrm{~cm} \cdot y^{-1}{ }^{-1}$ for young plants (Nobel and PimientaBarrios, 199.5) and $10 \mathrm{~cm} \cdot \mathrm{year}^{-1}$ for mature plants. Wild perennials growing in infertile soils tend to be long-lived with slow growth and a low capacity for photosynthesis and nutrient absorption, allowing such plants to maintain growth and reproduction even during periods of low water availability (Grime, 1979; Chapin, 1980).

The asynchronous pattern of flower and fruit production, which may be especially advantageous during adverse environmental conditions, was not affected by irrigation. Irrigation did not influence the rate of flower bud extension, but its period was lengthened by 9 days, resulting in larger flowers. The length enhancements resulting from irrigation during the last stages of flower bud and fruit growth suggest that such growth occurs through cell elongation, as for other fleshy fruit (Coombe, 1976; Zanchin et al., 1994). The time to reach maturity for $S$. queretaroensis fruit was relatively short compared with other cacti (e.g., Opuntia spp.), peach, plum, apples, and avocado (Barbera et al., 1992; Lee and Young, 1983; Ryugo, 1988).

Seed development for $S$. queretaroensis occurredunder drought, with irrigation increasing seed number but not seed size. Embryo abortion often results when water stress occurs after pollination, reducing the number of seeds produced; when water is withheld late during development, embryo abortion generally does not occur, although seed size may be reduced (Bradford, 1994). Seed maturation occurred just before the start of the summer rainy season, so seed germination and seedling establishment can occur under favorable environmental conditions. In contrast, seed development for Opuntia in the same region occurs during the rainy season and mature seeds show a dormancy period of 7 to 8 months; under natural conditions its seed germination is initiated at the start of the rainy season of the next year (Pérez and Pimienta, 1995). The seeds of Opuntia are larger than those of $S$. queretaroensis, are not light-requiring, and can germinate even when buried in the soil.

Seeds of $S$. queretaroensis contain a relatively large amount of lipid and germinate in response to light. Seeds of many wild species that respond to light are also small and rich in lipids; because of their small size and light requirement, such seeds must be near the soil surface for successful seedling establishment (Salisbury and Ross, 1992). The germination rate was higher for $S$. queretaroensis receiving irrigation. Seed and stem properties of $S$. queretaroensis are similar to those of undomesticated species, reflecting the relatively recent cultivation of this species for its fruit.

\section{Literature Cited}

Barbera, G., F. Carimi, and P. Inglese. 1992. Physical, morphological and chemical changes during fruit development and ripening in three cultivars of prickly pear, Opuntia ficus-indica (L.) Miller. J. Hort. Sci. 67:307-312.

Bradford, J.K. 1994. Water stress and the water relations of seed development: A critical review. Crop Sci. 34: 1-1 1.

Bravo, H.H. 1978. Lascactaceas de Mexico. 2nded. Universidad Nacional Autonoma de Mexico. Mexico City.

Carnal, W.C. and C.C. Black. 1989. Soluble sugars as the carbohydrate reserve for CAM in pineapple leaves. Plant Physiol. 90:91-100.

Chapin, S.F. 1980. The mineral nutrition of wild plants. Annu. Rev. Ecol. Syst. 11:233-260.

Choe, T.H. and K. Thimann. 1975. The metabolism of oat leaves during 
senescence. III. The senescence of isolated chloroplasts. Plant Physiol. 55:828-834.

Coombe, B.G. 1976. The development of fleshy fruits. Annu. Rev. Plant Physiol. 27:507-528.

Grime, P.J. 1979. Plant strategies and vegetation processes. Wiley, New York.

Haissig, B.E. and R.E. Dickson. 1979. Starch measurements in plant tissue using enzymatic hydrolysis. Plant Physiol. 47:151-157.

Harborne, J.B. 1984. Phytochemical methods: A guide to modem techniques of plant analysis. Chapman and Hall, London.

Jansen, H.D. 1967. Synchronization of sexual reproduction of trees within the dryseason in Central America. Evolution 21:620-637.

Kozlowski, T.T., P.J. Kramer, and S.G. Pallardy. 1991. The physiological ecology of woody plants. Academic Press, San Diego.

Lee, S.K. and R.E. Young. 1983. Growth measurements as an indication of avocado maturity. J. Amer. Soc. Hort. Sci. 108:395-397.

Lomeli, E. and E. Pimienta. 1993. Demografía reproductiva del pitayo (Stenocereus queretaroensis (Web.) Buxbaum). Revista Cactaceas Suculentas Mexicanas 38:13-19.

Longino, T.J. 1986. The causes and consequences of synchronous flushing in dry tropical forest. Biotropica 16:193-201.

Lowry, O.H., N.J. Roseborough, A.L. Farr, and R.J. Randall. 1951. Protein measurements with the Folin phenol reagent. J. Biol. Chem. 193:265-275.

Nerd, A., E. Raveh, and Y. Mizrahi. 1993. Adaptation of five columnar species to various conditions in the Negev Desert of Israel. Econ. Bot. 47:304-311.
Nobel, P.S. and E. Pimienta-Barrios. 1995. Monthly stem elongation for Stenocereus queretaroensis: Relationships to environmental conditions, net $\mathrm{CO}_{2}$ uptake, and seasonal variations in sugar content. Environ. Expt. Bot. 35: 17-24.

Parker, K.C. 1988. Growth rates of Stenocereus thurberi and Lophocereus schottii in southern Arizona. Bot. Gaz. 149:335-346.

Pérez, R.C. and E. Pimienta B. 1995. Viabilidad de semillas y poliembrionia en morfoespecies cultivadas y silvestres de Opuntia. Agrociencia (In press.)

Pimienta-Barrios, E. and P.S. Nobel. 1994. Pitaya (Stenocereus spp., Cactaceae): An ancient and modem fruit crop of Mexico. Econ. Bot. 48:76-83.

Robles, M.C. 1994. Estudio anatómico-fisiológico comparative entre el nopal (Opuntia ficus-indica (L.) Miller) y el pitayo (Stenocereus queretaroensis (Web.) Buxbaum). Facultad de Ciencias Biologicas, Universidad de Guadalajara, Guadalajara, Jalisco.

Ryugo, K. 1988. Fruit culture. Wiley, New York.

Salisbury, B.F. and C.W. Ross. 1992. Plant physiology. 4th ed. Wadsworth, Belmont, Calif.

Sturgeon R.J. 1990. Monosaccharides, p. 1-37. In: P.M. Dey and J.B. Harborne (eds). Methods in plant biochemistry. vol. 2. Carbohydrates. Academic Press, London.

Sutton B.G. 1975. The path of carbon in CAM plants at night. Austral. J. Plant Physiol. 2:377-387.

Zanchin, A., C. Bonghi, G. Casadoro, A. Ramina, and N. Rascio. 1994. Cell enlargement and cell separation during peach fruit development. Intl. J. Plant Sci. 155:49-56. 